\title{
Estimation of potential soil erosion rate using RUSLE and $\mathbf{E}_{30}$ model
}

\author{
Sailesh Samanta ${ }^{1}$ (D) Cathy Koloa $^{2} \cdot$ Dilip Kumar Pal $^{2} \cdot$ Babita Palsamanta $^{3}$
}

Received: 15 July 2016/ Accepted: 26 July 2016/Published online: 6 August 2016

(C) Springer International Publishing Switzerland 2016

\begin{abstract}
This research established an empirical methodology to estimate potential soil erosion rate based on revised universal soil loss equation (RUSLE) and $\mathrm{E}_{30}$ model. The study was conducted on a highly precipitated, rugged, tropical forested with steep slope watershed during 1992 to 2009. The fourth (4th) largest river of Papua New Guinea, and its catchment area was considered for this research. Lots of commercial mining and logging activities are the ongoing processes in the upper catchment area without proper conservation measures. Digital elevation model (DEM), landsat satellite images, average annual rainfall, soil texture data base were used to derived mandatory input factors into the RUSLE and $\mathrm{E}_{30}$ model. Raster calculator of ArcGIS spatial analyst was used to generate all input factors and final pixel-by-pixel based computation of soil loss pattern. The average potential soil erosion rate were calculated in the range of $20.34 \mathrm{~mm} / \mathrm{year}$
\end{abstract}

Sailesh Samanta

rsgis.sailesh@gmail.com

Cathy Koloa

cmkoloa@gmail.com

Dilip Kumar Pal

dkpa1200090@gmail.com

Babita Palsamanta

mundey2@gmail.com

1 GIS Section, Department of Surveying and Land Studies, The PNG University of Technology, Private Mail Bag, Lae, Morobe, Papua New Guinea

2 Department of Surveying and Land Studies, The PNG University of Technology, Private Mail Bag, Lae, Morobe, Papua New Guinea

3 The PNG University of Technology Campus, Private Mail Bag, Lae, Morobe, Papua New Guinea to $23.70 \mathrm{~mm} /$ year through RSULE model and in the other hand the rate varies from $21.07 \mathrm{~mm} /$ year to $26.78 \mathrm{~mm} / \mathrm{year}$ through $\mathrm{E}_{30}$ model during 1992 to 2009 respectively. The erosion rate through both model indicates extremely severe rate of erosion in the upper catchment area are required immediate attention of soil conservation practices.

Keywords RUSLE model $\cdot \mathrm{E}_{30}$ model $\cdot$ NDVI $\cdot$

Watershed $\cdot$ Remote sensing $\cdot$ GIS

\section{Introduction}

Soil is one of the most valuable natural resource (Kouli et al. 2009) in any agriculture based developing nation. Soil erosion is a critical lively processed and serious environmental problem caused by many natural and human activities. Quantitative data on rates soil erosion in the national scale are very much essential to develop soil conservation and management plans and to asses environmental implications (Alexakis et al. 2013). Different onsite effects of soil erosion (Pimentel 2006) like loss of top soil, change of soil structure, loss of soil organic matter content which leads to reduction of productivity and on the other hand offsite events (Sinha and Joshi 2012) like reduction of channel depth, water holding, water discharge and transport capacity of a stream (Zhou and Wu 2008) caused increase of flood intensity and frequency. In a hilly and steep sloppy region soil erosion may initiate landslide (Michael and Samanta 2016) as a short term and degradation of soil quality as long term effects. The erosion in upper catchment area depends on amount of rainfall, vegetation cover, soil characteristics, slope (Pal et al. 2012) and accelerated by human activity like mining, agriculture and deforestation. In last two decades several studies and 
empirical models were developed by many researches (Morgan et al. 1998; Kim and Julien 2006; Darbral et al. 2008; Melesse et al. 2011) to estimate soil erosion in different region around the globe. The use of remote sensing and GIS techniques is very useful in estimation of total soil loss (Prasannakumar et al. 2011; Koloa and Samanta 2013) and soil erosion rate spatially and temporally with minimum costs and better accuracy in larger areas (Rahman et al. 2009). Revised universal soil loss equation (RUSLE) is one of the most familiar soil loss estimation process based on ground based observation and remote sensing and GIS technology (Pandey et al. 2007; Sharma 2010; Pal and Samanta 2011). Other empirical model is named as $E_{30}$ to calculate the rate of soil erosion in any region (Honda et al. 1996; Hazarika and Honda 2001; Bagyaraj et al. 2014) where hydrological, meteorological, geographical and river morphological data are limited (Udayakumara et al. 2010). It is best to measure soil erosion rate in a catchment area. Preparation of digital data base is first essential task to generate factors/parameters (Samanta et al. 2012) which are mandatory to be incorporated into RUSLE or $\mathrm{E}_{30}$ model. The study was aimed to assess the applicability of GIS based RUSLE and $\mathrm{E}_{30}$ model for determination of soil erosion risk zone in Markham catchment, which is mostly comes under Morobe province of Papua New Guinea. The main objective of this research was to estimate soil loss through RUSLE and $\mathrm{E}_{30}$ model and to comparative analysis of soil erosion results obtained from both model in the Markham catchment.

\section{Study location and materials used}

This research work was attempted in the fourth (4th) largest catchment of Papua New Guinea. The Markham catchment is located in the eastern part of main island. Most of the area falls under Morobe province and small portion in the north and north-east of the study area comes under Madang and Eastern highland province, respectively (Fig. 1). The study area includes a geographical area extending from $145^{\circ} 58^{\prime} 27.39^{\prime \prime} \mathrm{E}$ to $147^{\circ} 02^{\prime} 22.01^{\prime \prime} \mathrm{E}$ and $5^{\circ} 51^{\prime} 19.41^{\prime \prime} \mathrm{S}$ to $7^{\circ} 31^{\prime} 21.93^{\prime \prime} \mathrm{S}$. Markham river is originated from Finisterre range $\left(5^{\circ} 51^{\prime} 36.31^{\prime \prime} \mathrm{S}\right.$ and $\left.146^{\circ} 13^{\prime} 22.40^{\prime \prime} \mathrm{E}\right)$ in the north and gets emptied into Huon Gulf $\left(6^{\circ} 44^{\prime} 20^{\prime \prime} \mathrm{S} 146^{\circ} 58^{\prime} 05^{\prime \prime}\right)$ in the east after $180 \mathrm{~km}$ of chequered path (Fig. 1). Erap and Watut are two major tributary rivers of Markham. Upper catchment area of Markham is dominated by dense forests, rugged topography and steep slopes. Lack of proper soil conservation and management measure are exacerbated by commercial logging, mining and small scale mining on the river for alluvial gold extraction. The study area is characterised with tropical hot and humid climate with an average rainfall of $4200 \mathrm{~mm}$. Markham carries flows from the $12,450 \mathrm{~km}^{2}$ catchment with huge mobile bed load ranging from fine silt to cobbles (Tilley et al. 2006).

For this research three different satellite images during 1992 to 2009 were collected from earth explorer (http:// www.earthexplorer.usgs.gov) to generate normalised differential vegetation index (NDVI) data base for different year (1992, 2001 and 2009). Digital elevation model (DEM) in $30 \mathrm{~m}$ spatial resolution was collected from Advanced Space Thermal Emission Radiometer (ASTER) mission to produce slope map of the study area. All other collateral information that were used in this study are given in Table 1. For RUSLE model different factors like rainfall erosivity factor (R), vegetation cover factor (C), soil erodibility factor $(\mathrm{K})$, slope length \& steepness factor (LS) and existing soil conversion measures factor $(\mathrm{P})$ were used as a mandatory input parameters, which were developed using ArcGIS spatial analyst tool from rainfall, elevation and soil data base. On the other hand rate minimum and maximum of erosion in 30 degree slope area, NDVI, and slope data base were used to calculate rate of soil erosion through $\mathrm{E}_{30}$ model.

\section{Methodology}

Multi-temporal (1992 to 2009) satellite images of Landsat thematic mapper (TM) and enhancement thematic mapper plus $(\mathrm{ETM}+)$ were used in this study. Four satellite images (path/row: 96/64, 96/65, 97/64 and 97/65) were collected to cover entire study area. All satellite images were geo-referenced carefully using universal transverse mercator (UTM) projection system, second order polynomial transformation and nearest neighbour resample method. The range of root mean square error of the transformation varies from 0.09 to 0.15 which is much lower than the pixel size $(30 \mathrm{~m})$ of the satellite data. All satellite images and digital elevation data were cropped with the Markham catchment boundary and the entire catchment was marked with of 14 sub-catchments based on elevation, contour, drainage pattern and drainage order (Fig. 1). Maximum slope (more than 80 degree) is found in the sub-catchment number 3 .

$\mathrm{E}_{30}$ and RUSLE model were used to estimate the rate of soil erosion in the Markham catchment. To execute $\mathrm{E}_{30}$ model Normalised differential vegetation index (NDVI) and the slope gradient were used as two major parameter. Aster DEM data was used to develop slope data base (Paz and Collischonn, 2007; Warren et al. 2004) for the study area. NDVI was calculated using a simple band rationing technique $(\mathrm{NDVI}=\mathrm{B} 4-\mathrm{B} 3 / \mathrm{B} 4+\mathrm{B} 3)$ using band 4 (Near-infrared) and Band 3 (Red) of landsat satellite image (Lillesand et al. 2007). NDVI value (ranged from +1 to -1 ) is the measure of vegetation coverage of an area 

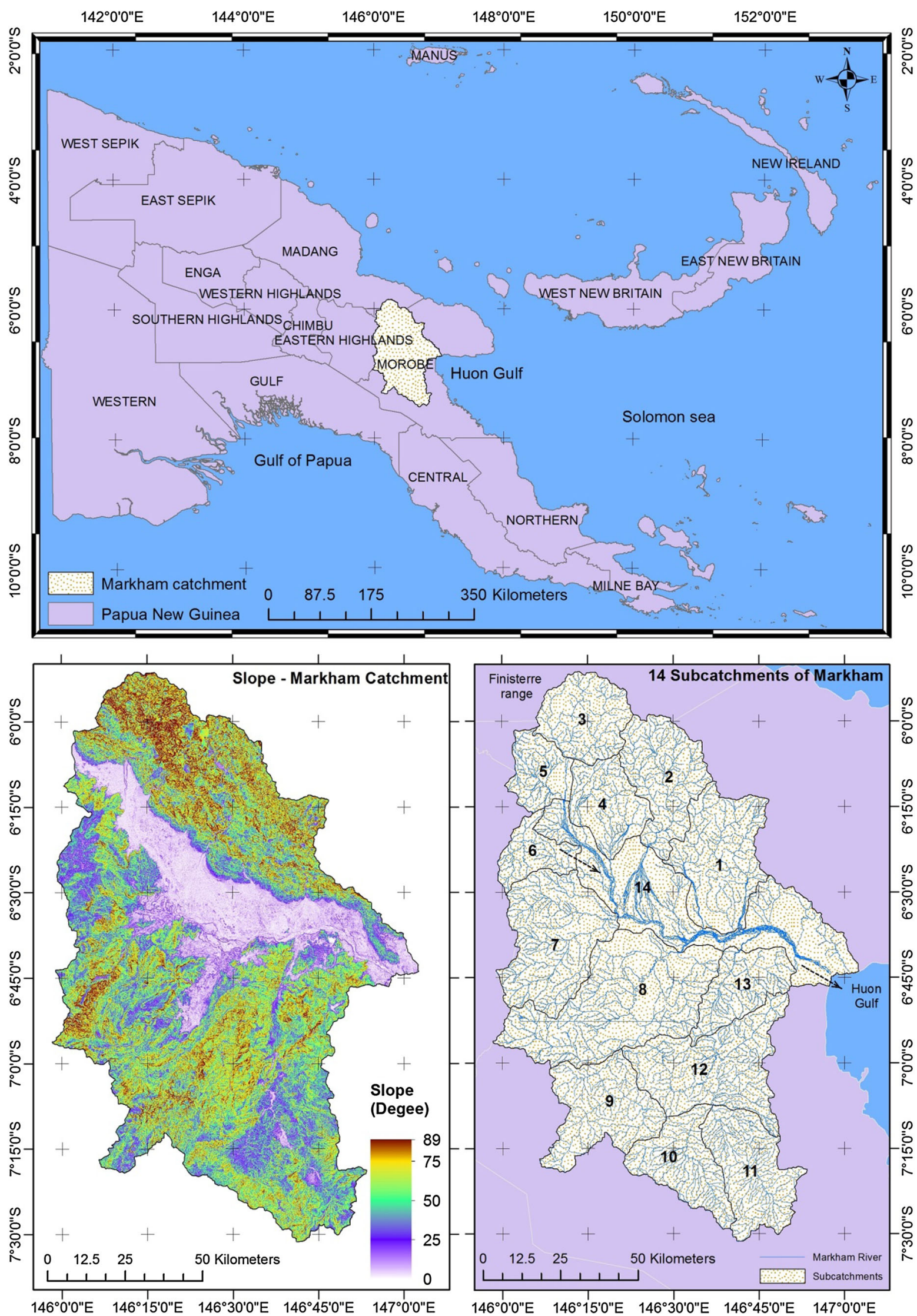

$146^{\circ} 0^{\prime} 0^{\prime \prime E} \quad 146^{\circ} 15^{\prime} 0$ "E $146^{\circ} 30^{\prime} 0^{\prime \prime E} \quad 146^{\circ} 45^{\prime} 0^{\prime \prime E} \quad 147^{\circ} 0^{\prime} 0^{\prime \prime E}$

Fig. 1 Location map with details of slope and sub catchments of the study area 
Table 1 List of data used in the study

\begin{tabular}{llll}
\hline Materials & Scale/cell size & Year & Source \\
\hline Landsat TM & $30 \mathrm{~m}$ & 1992,2009 & http://www.earthexplorer.usgs.gov \\
Landsat ETM+ & $30 \mathrm{~m}$ & 2001 & \\
National soil atlas & $1: 250,000$ & 2009 & Geobook \\
Administrative boundary, drainage & $1: 250,000$ & 2009 & PNGRIS \\
Rainfall & $1: 250,000$ & $1972-2009$ & Geobook \\
ASTER DEM data & $30 \mathrm{~m}$ & 2003 & ftp://e0srp01u.ecs.nasa.gov \\
\hline
\end{tabular}

(Zhou et al. 2008). $E_{30}$ model is expressed in the Eq. (1) based on the previous researches (Hazarika and Honda 2001; Gunawan et al. 2013).

$E=E_{30} \times\left(S / S_{30}\right)^{0.9}$

where, $\mathrm{E}$ is the rate of soil erosion ( $\mathrm{mm} /$ year), $\mathrm{S}$ represents the slope gradient of the area in degree and $S_{30}$ refers to tan $30^{\circ}$ and $\mathrm{E}_{30}$ refers to the soil erosion at $30^{\circ}$ slope within the study area which was calculated based on Eq. (2) (Hazarika and Honda 2001).

$$
\begin{aligned}
E_{30}= & \operatorname{Exp}\left[\left(\left\{\log E_{\max }-\log E_{\min }\right) /\left(N D V I_{\max }-N D V I_{\min }\right\}\right)\right. \\
& \left.\times\left(N D V I_{\max }-N D V I_{\min }\right)+\log E_{\max }\right]
\end{aligned}
$$

where, $\mathrm{NDVI}_{\text {max }}$ and $\mathrm{NDVI}_{\text {min }}$ are the maximum and the minimum NDVI values, $\mathrm{E}_{\min }$ and $\mathrm{E}_{\max }$ are the minimum and the maximum rate of soil erosion at $30^{\circ}$ slope. Maximum and minimum rate soil erosion at $30^{\circ}$ slope in the study area were 14.8 and $1.5 \mathrm{~mm} /$ year.

Computation of soil loss was achieved using revised universal soil loss equation (Koloa and Samanta 2013) is described as Eq. (3).

$A=R \times K \times L S \times C \times P$

where, A stands for the average annual soil loss at a cell ( $\mathrm{t}$ ha/year), $\mathrm{R}$ represents the rainfall and runoff erosivity factor at a geographic location (MJ mm ha/h/year), $\mathrm{K}$ refers the soil erodibility factor, LS is slope steepness and length factor for a cell, $\mathrm{C}$ is the cover management factor and $\mathrm{P}$ is the conservation support practice factor at a cell.
Rainfall was obtained from national database (Geobook 2009) of Papua New Guinea and used to calculate R factor using Eq. (4) (Parveen and Kumar 2012).

$R=79+0.363 R_{N}$

where, $R_{N}$ is the average annual rainfall in $\mathrm{mm}$

Soil erodibility factor ( $\mathrm{K}$ factor) was calculated based the soil texture type as presented in the Table 2. Topographic factor (LS) was derived using Eq. (5) in bellow (Tirkey et al. 2013).

$$
\begin{aligned}
L S= & ([\text { Flow accumulation }] \times \text { cell size } / 22.13)^{n} \\
& \times(\operatorname{Sin}([\text { slope }] \times 0.01745) / 0.0896)^{m} \times 1.4
\end{aligned}
$$

where, flow direction was derived from ASTER DEM, The flow accumulation correspond to the drainage in the catchment, value of $\mathrm{n}$ is 0.4 and $\mathrm{m}$ is 1.4 .

The $\mathrm{C}$ factor database were generated from NDVI result for each year. The $\mathrm{C}$ factor values vary between 0 and 1 based on types of land covers excluding water area (Karaburun 2010). Many other researchers also used regression analysis to estimate $\mathrm{C}$ factor values for land cover classes in erosion assessment (Van der Knijff 2000; Symeonakis and Drake 2004; Lin et al. 2006). The regression equation was expresses as bellow Eq. (6).

$C=1.02-1.21 * N D V I$

The $\mathrm{P}$ factor was considered according to the up and down slope (Pal and Samanta 2011) of the area which was verified with field-level investigations (Table 3 ). In this

\begin{tabular}{|c|c|c|c|}
\hline Code & Soil erodibility & Description & $\mathrm{K}$ factor \\
\hline 1 & Very low & Soils with high to very high organic matter content and moderate to rapid permeability & 0.07 \\
\hline 2 & Low & $\begin{array}{l}\text { Except for sandy Entisols, these soils have moderate organic matter content } \\
\text { and moderate permeability }\end{array}$ & 0.17 \\
\hline 3 & Moderate & $\begin{array}{l}\text { Generally slowly permeable soils with moderate organic matter content; } \\
\text { the alluvial Entisols have low to moderate organic matter content }\end{array}$ & 0.27 \\
\hline 4 & High & Poorly structured top soils & 0.37 \\
\hline
\end{tabular}
area, no tillage practices are noticed. Therefore, these are not taken into account due to their very less spatial extent.

Table $2 \mathrm{~K}$ factors for different soil erodibility class 
Table $3 \mathrm{P}$ factors for different slope of Markham

\begin{tabular}{lll}
\hline S1 no. & Slope (percent) & Support practice factor \\
\hline 1 & $0-7$ & 0.6 \\
2 & 714 & 0.7 \\
3 & $14-21$ & 0.8 \\
4 & $21-28$ & 0.9 \\
5 & More than 28 & 1.0 \\
\hline
\end{tabular}

Raster calculator tool in ArcGIS 10.0 spatial analyst extension was used to incorporated all input parameters and raster based out puts were generated.

RUSLE output of average total soil loss (ton ha/year) was converted into rate of soil erosion ( $\mathrm{mm} / \mathrm{year}$ ) based on Schertz 1983. Soil conservation programs consider soil-loss tolerance values ( $\mathrm{T}$ ) values to be $5-12$ tons/ha/ year (30), equivalent to $0.4-1 \mathrm{~mm} / \mathrm{year}$ of erosion (Montgomery 2007), assuming a soil bulk density of $1200 \mathrm{~kg} / \mathrm{m}^{3}$.

\section{Result and discussion}

The modelled output on rates of soil erosion based on $\mathrm{E}_{30}$ and RUSLE model were classified into seven (7) categories. They were 0-5 (extremely low), 5-10 (very low), 10-15 (low), 15-20 (medium), 20-25 (high), 25-30 (very high) and more than $30 \mathrm{~mm} /$ year (extremely high) respectively (Figs. 2, 3). Class wise statistics (histogram, area in hectare and percentage) were generated after conversion of total histogram for each categories of erosion rate (Table 4). According to the $\mathrm{E}_{30}$ model most of the area were marked with the erosion rate of more than $20 \mathrm{~mm} /$ year in 1992 and 2001, whereas more than $25 \mathrm{~mm}$ /year in 2009 (Fig. 2). The RUSLE model predicted erosion rate in most of the area comes under less than $5 \mathrm{~mm} /$ year followed by more than $30 \mathrm{~mm} / \mathrm{year}$ for each year of study (Fig. 3). The result showed that the erosion rate increases with the increase of slope. The calculated erosion rate through both models was found to be exceeded $20 \mathrm{~mm} /$ year in the upper catchment area due to the steep slope. In 2009 based on $E_{30}$ model average rate of erosion was calculated as $2.5 \mathrm{~mm} /$ year in the $0^{\circ}-5^{\circ}$ slope and $37.5 \mathrm{~mm} /$ year in the $30^{\circ}-40^{\circ}$ slope respectively. The increase rate of soil erosion, 15 times due to change of slope from $0^{\circ}-5^{\circ}$ to $30^{\circ}-40^{\circ}$ is the indication of extreme rate of soil erosion in the hilly region with steep slope. NDVI refers an index of vegetation depending on the intensity of red and near-infrared band. High density vegetation refers higher NDVI value. Calcu- lated maximum NDVI values were decreased from 0.75 in 1992 to 0.65 in 2009. In RUSLE model NDVI is only one parameter which was differed from 1 year to another which was used to calculate c-factor. With the decreased of NDVI values average rate of erosion was increased by $3.36 \mathrm{~mm} /$ year in 2009 than year 1992. On the other hand based on $\mathrm{E}_{30}$ model, the rate of erosion was increased by $5.71 \mathrm{~mm} /$ year in 2009 as NDVI was incorporated to calculate the soil erosion at $30^{\circ}$ slope.

According to $\mathrm{E}_{30}$ model average rate of soil erosion was calculated as $21.07 \mathrm{~mm} /$ year in 1992, $21.80 \mathrm{~mm} /$ year in 2001 and $26.78 \mathrm{~mm} /$ year in 2009, respectively (Fig. 2). On the other hand the average soil erosion was estimated at the rate of $20.34 \mathrm{~mm} /$ year in 1992, $21.24 \mathrm{~mm} /$ year in 2001 and $23.70 \mathrm{~mm} /$ year in 2009, respectively through RUSLE model (Fig. 3). The correlation (r) between two model estimation was calculated 0.9897 (Fig. 4). Within the catchment area maximum average soil erosion rate, $54.83 \mathrm{~mm} /$ year was found in sub-catchment number three (3), followed by sub-catchment $2,52.68 \mathrm{~mm} /$ year and minimum of $6.64 \mathrm{~mm} /$ year in sub-catchment 14 based on RUSLE model in 2009 (Table 5; Fig. 5). The average soil erosion rate of 45.07, 41.07 and $9.97 \mathrm{~mm} /$ year were yield by $\mathrm{E}_{30}$ model in the sub-catchment number 3,2 and 14 , respectively (Table 5; Fig. 5). The correlation (r) of estimated average soil erosion rate for 14 sub-catchments through both models was calculated as 0.90 , which indicates a good relationship of the estimations (Fig. 6). The average slope of was calculated as $30.07^{\circ}$ in sub-catchment number $2,25.39^{\circ}$ in sub-catchment number 3 and $6.57^{\circ}$ in sub-catchment number 14 (Table 5). Result suggested that the slope is the major factor for both model in the estimation of soil erosion rate. The comparative analysis was carried out to find out correlation (r) between slope and average estimated soil erosion rate in 14 sub-catchments area by both models in 2009. The correlations with slope and RUSLE model was calculated as 0.89 and for $\mathrm{E}_{30}$ model as 0.99 (Fig. 7).

\section{Conclusion}

Slope of the land, NDVI, soil erosion in $30^{\circ}$ slope were considered as mandatory inputs into $\mathrm{E}_{30}$ model, where as rainfall and runoff erosivity ( $\mathrm{R}$ factor), soil erodibility ( $\mathrm{K}$ factor), slope steepness and length (LS factor), cover management (C factor) and conservation support practice (P factors) were used into the RUSLE model. Expectedly, some difference in the estimation were likely to crop up in 

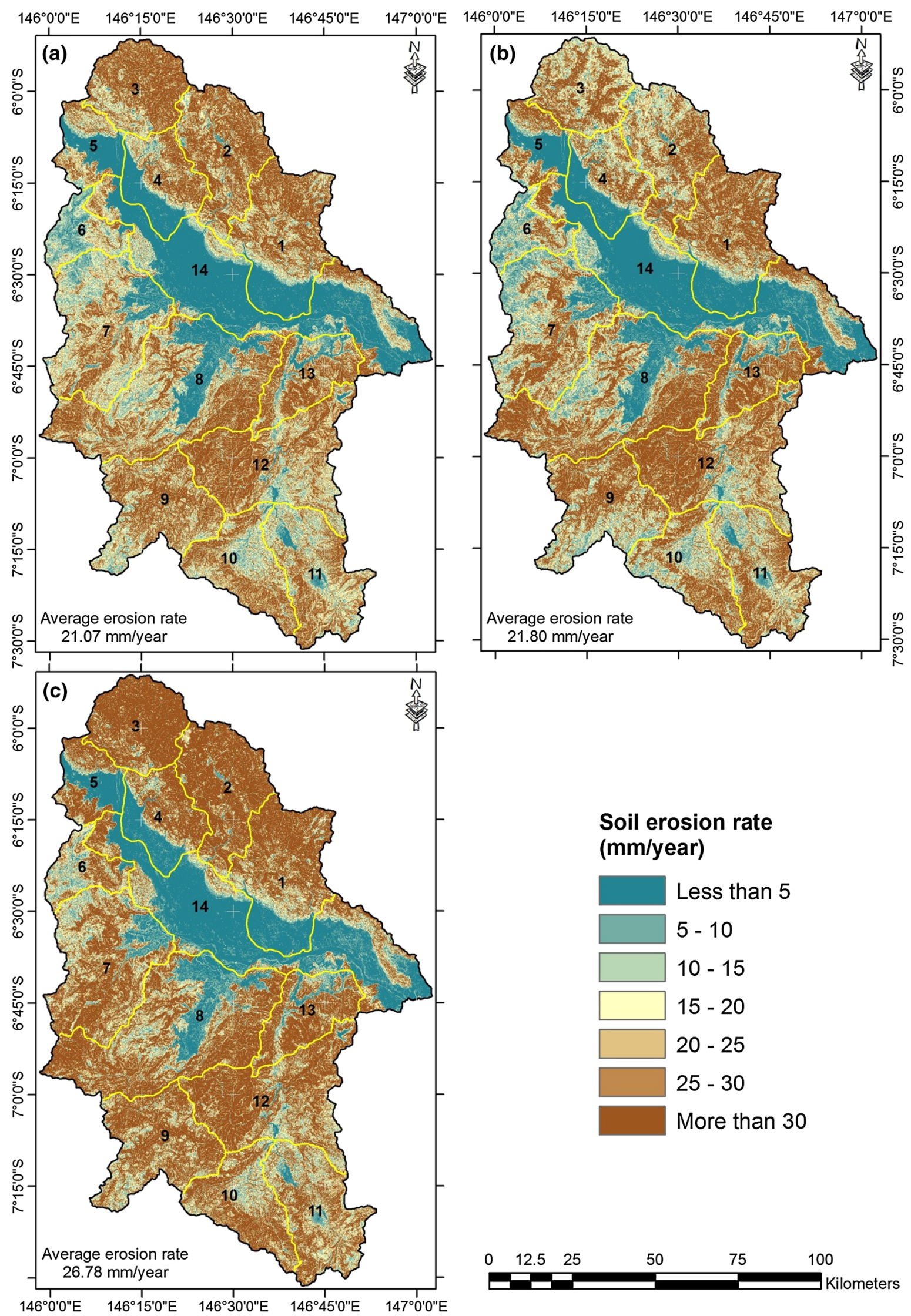

\section{Soil erosion rate (mm/year)}
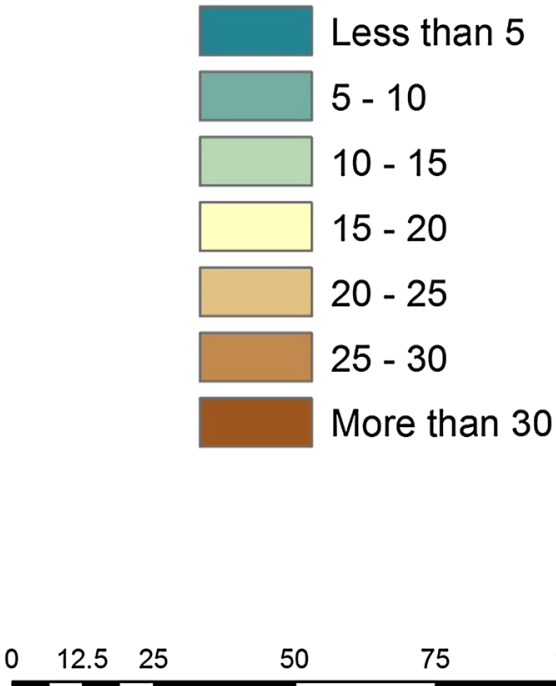

75

100

$146^{\circ} 0^{\prime} 0^{\prime \prime E} \quad 146^{\circ} 15^{\prime} 0^{\prime \prime E} \quad 146^{\circ} 30^{\prime} 0^{\prime \prime E} \quad 146^{\circ} 45^{\prime} 0^{\prime \prime}$ E $147^{\circ} 0^{\prime} 0^{\prime \prime E}$

Kilometers

Fig. 2 Soil erosion rate base on $\mathrm{E}_{30}$ model for year 1992 (a), 2001 (b) and 2009 (c) 

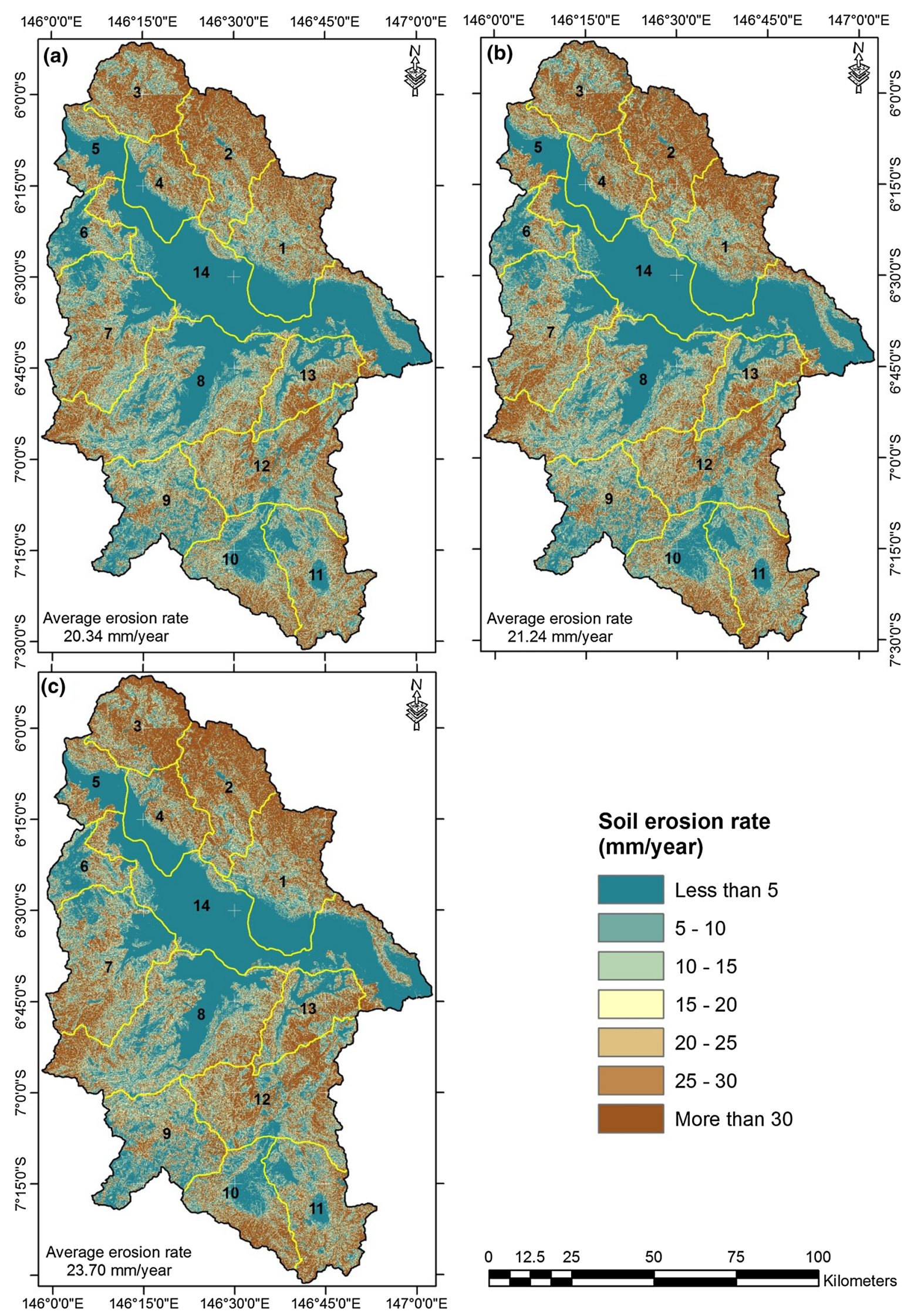

\section{Soil erosion rate (mm/year)}

\begin{tabular}{|c|}
\hline Less than 5 \\
\hline $5-10$ \\
\hline $10-15$ \\
\hline $15-20$ \\
\hline $20-25$ \\
\hline $25-30$ \\
\hline More than 30 \\
\hline
\end{tabular}

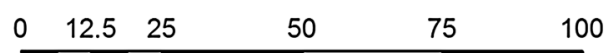

Kilometers

Fig. 3 Soil erosion rate base on RUSLE model for year 1992 (a), 2001 (b) and 2009 (c) 
Table 4 Categories of rates of soil erosion and detail statistics

\begin{tabular}{|c|c|c|c|c|c|c|}
\hline Soil loss (mm/year) & $\mathrm{E}_{30} 1992$ & $\mathrm{E}_{30} 2001$ & $\mathrm{E}_{30} 2009$ & RUSLE 1992 & RUSLE 2001 & RUSLE 2009 \\
\hline \multicolumn{7}{|l|}{ Histogram } \\
\hline Less than 5 & $2,491,469$ & $2,466,920$ & $2,182,377$ & $4,883,663$ & $4,936,960$ & $4,858,489$ \\
\hline $5-10$ & $1,138,158$ & $1,301,121$ & 937,249 & $1,851,917$ & $1,747,898$ & $1,686,835$ \\
\hline $10-15$ & $1,402,554$ & $1,465,952$ & 980,955 & $1,455,151$ & $1,387,182$ & $1,341,014$ \\
\hline $15-20$ & $1,629,029$ & $1,622,235$ & $1,234,056$ & $1,161,807$ & $1,117,144$ & $1,084,196$ \\
\hline $20-25$ & $1,865,332$ & $1,604,092$ & $1,419,134$ & 946,812 & 904,461 & 879,423 \\
\hline $25-30$ & $1,781,757$ & $1,493,067$ & $1,460,046$ & 755,824 & 725,253 & 710,424 \\
\hline More than 30 & $3,858,371$ & $4,213,283$ & $5,952,853$ & $3,111,496$ & $3,347,772$ & $3,606,289$ \\
\hline Total & $14,166,670$ & $14,166,670$ & $14,166,670$ & $14,166,670$ & $14,166,670$ & $14,166,670$ \\
\hline \multicolumn{7}{|l|}{ Area in hectare } \\
\hline Less than 5 & 2242.32 & 2220.23 & 1964.14 & 4395.30 & 4443.26 & 4372.64 \\
\hline $5-10$ & 1024.34 & 1171.01 & 843.52 & 1666.73 & 1573.11 & 1518.15 \\
\hline $10-15$ & 1262.30 & 1319.36 & 882.86 & 1309.64 & 1248.46 & 1206.91 \\
\hline $15-20$ & 1466.13 & 1460.01 & 1110.65 & 1045.63 & 1005.43 & 975.78 \\
\hline $20-25$ & 1678.80 & 1443.68 & 1277.22 & 852.13 & 814.01 & 791.48 \\
\hline $25-30$ & 1603.58 & 1343.76 & 1314.04 & 680.24 & 652.73 & 639.38 \\
\hline More than 30 & 3472.53 & 3791.95 & 5357.57 & 2800.35 & 3012.99 & 3245.66 \\
\hline Total & $12,750.00$ & $12,750.00$ & $12,750.00$ & $12,750.00$ & $12,750.00$ & $12,750.00$ \\
\hline \multicolumn{7}{|l|}{ Area in percentages } \\
\hline Less than 5 & 17.59 & 17.41 & 15.41 & 34.47 & 34.85 & 34.30 \\
\hline $5-10$ & 8.03 & 9.18 & 6.62 & 13.07 & 12.34 & 11.91 \\
\hline $10-15$ & 9.90 & 10.35 & 6.92 & 10.27 & 9.79 & 9.47 \\
\hline $15-20$ & 11.50 & 11.45 & 8.71 & 8.20 & 7.89 & 7.65 \\
\hline $20-25$ & 13.17 & 11.32 & 10.02 & 6.68 & 6.38 & 6.21 \\
\hline $25-30$ & 12.58 & 10.54 & 10.31 & 5.34 & 5.12 & 5.01 \\
\hline More than 30 & 27.24 & 29.74 & 42.02 & 21.96 & 23.63 & 25.46 \\
\hline Total & 100.00 & 100.00 & 100.00 & 100.00 & 100.00 & 100.00 \\
\hline
\end{tabular}

Fig. 4 Comparison of erosion rate of $\mathrm{E}_{30}$ and RUSLE model for year 1992, 2001 and 2009

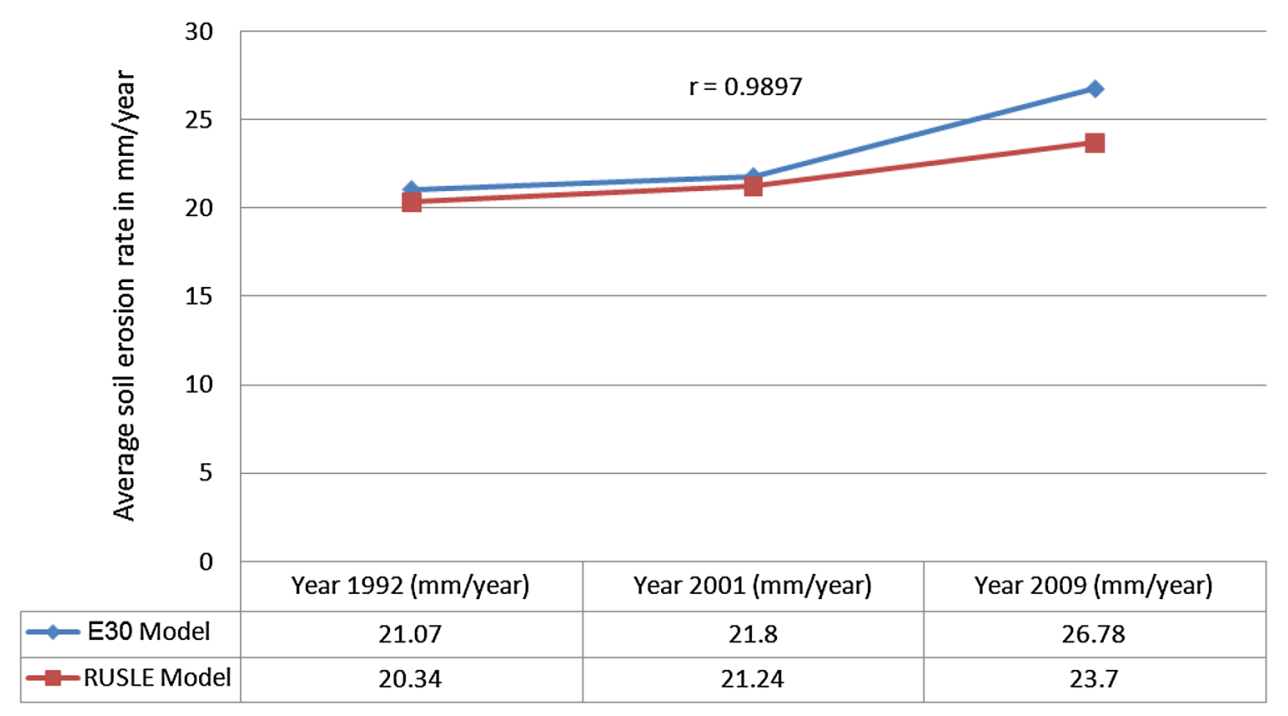


Table 5 Rates of soil erosion for all sub-catchments of Markham from 1992 to 2009

\begin{tabular}{|c|c|c|c|c|c|c|c|}
\hline \multirow[t]{2}{*}{ Sub-catchment } & \multicolumn{6}{|c|}{ Average soil erosion rate (mm/year) } & \multirow[t]{2}{*}{ Slope in degree } \\
\hline & $E_{30} 1992$ & $\mathrm{E}_{30} 2001$ & $E_{30} 2009$ & RUSLE 1992 & RUSLE 2001 & RUSLE 2009 & \\
\hline 1 & 22.64 & 24.46 & 27.00 & 22.89 & 27.87 & 28.64 & 18.57 \\
\hline 2 & 29.86 & 33.78 & 41.07 & 42.89 & 47.93 & 52.68 & 25.39 \\
\hline 3 & 31.17 & 35.21 & 45.07 & 43.19 & 47.75 & 54.83 & 30.07 \\
\hline 4 & 17.92 & 16.71 & 23.29 & 20.26 & 20.11 & 22.96 & 16.63 \\
\hline 5 & 14.45 & 17.26 & 21.58 & 13.73 & 16.54 & 17.15 & 13.93 \\
\hline 6 & 13.65 & 15.79 & 22.37 & 10.03 & 12.45 & 12.76 & 14.23 \\
\hline 7 & 18.91 & 20.61 & 27.20 & 17.76 & 19.52 & 20.66 & 18.18 \\
\hline 8 & 21.43 & 23.60 & 26.74 & 15.86 & 16.55 & 17.56 & 17.63 \\
\hline 9 & 26.56 & 26.21 & 31.17 & 15.51 & 15.78 & 16.57 & 21.50 \\
\hline 10 & 23.91 & 23.78 & 28.48 & 17.81 & 19.69 & 22.39 & 18.66 \\
\hline 11 & 22.00 & 23.71 & 25.10 & 21.79 & 22.47 & 23.46 & 17.14 \\
\hline 12 & 26.58 & 29.01 & 31.64 & 26.30 & 25.78 & 30.05 & 21.21 \\
\hline 13 & 24.77 & 27.74 & 30.18 & 23.47 & 22.85 & 27.77 & 19.18 \\
\hline 14 & 8.40 & 8.91 & 9.97 & 6.28 & 6.33 & 6.64 & 6.57 \\
\hline Total & 21.07 & 21.80 & 26.78 & 20.34 & 21.24 & 23.70 & 17.78 \\
\hline
\end{tabular}

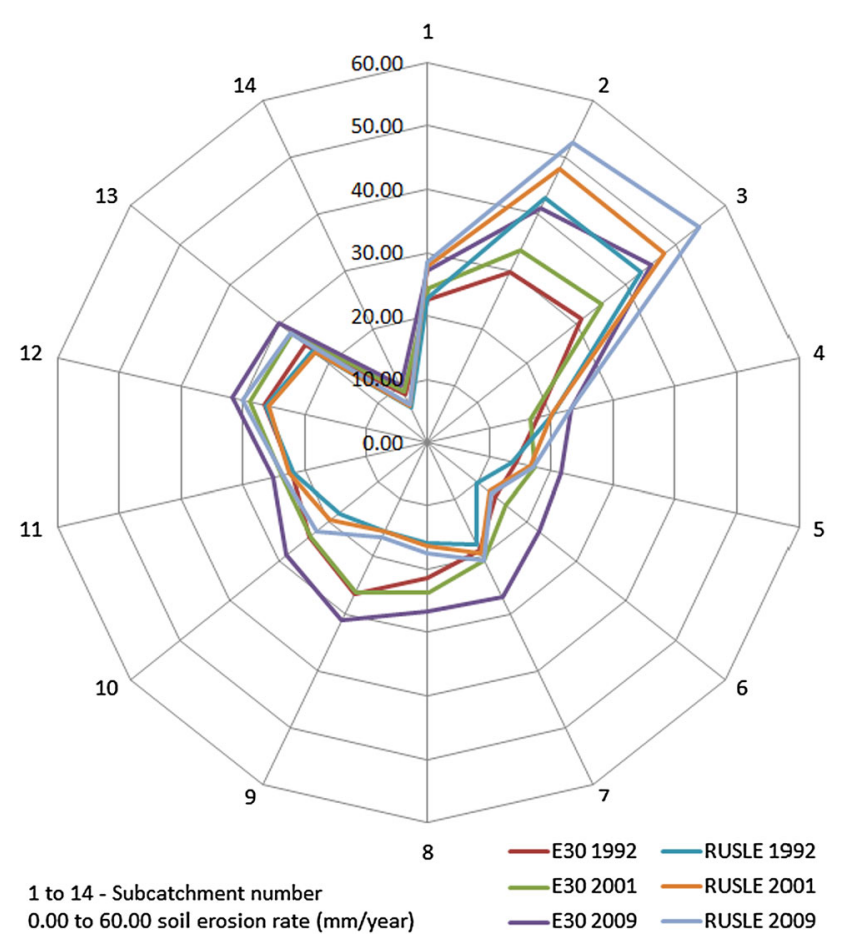

Fig. 5 Average erosion rate for sub-catchments of Markham for year 1992, 2001 and 2009

this research work. A closed relationship was calculated $(r=0.9897)$ between the estimation of soil erosion rate through $\mathrm{E}_{30}$ and RUSLE model. An increase rate of soil erosion rate was recorded almost in all sub-catchments area

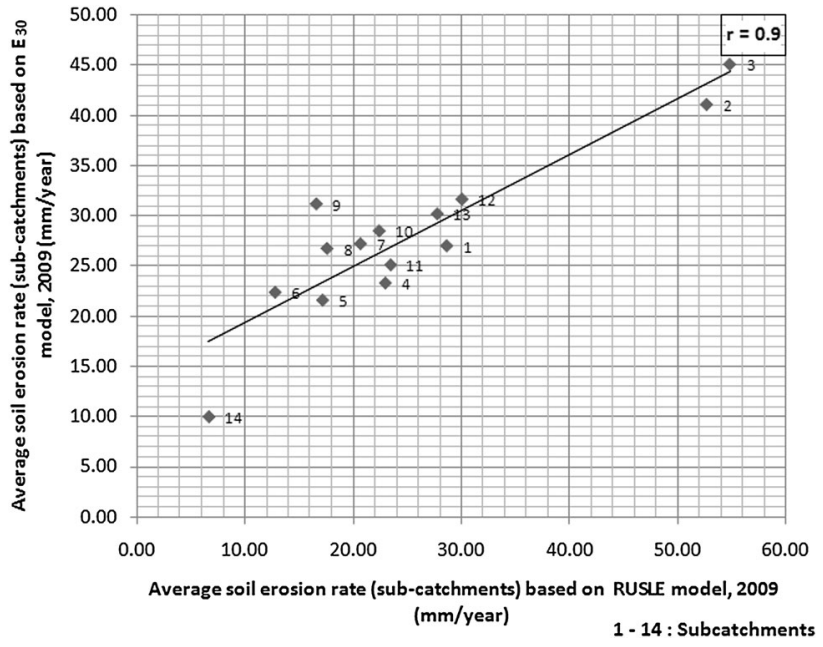

Fig. 6 Correlation of estimated average erosion rate for sub-catchments through $\mathrm{E}_{30}$ and RUSLE model

because of continuous loss of forest or vegetation cover caused by increased logging, agriculture and mining activity which resulted decrease of NDVI value year after year. The erosion rate through $\mathrm{E}_{30}$ and RUSLE model indicates extremely severe rate of erosion in the upper catchment area having rugged terrain and steep slope. These area are required immediate attention of soil conservation practices. This kind of research can be conducted in any other watershed region of Papua New Guinea to determine potential spatio-temporal soil loss pattern where 


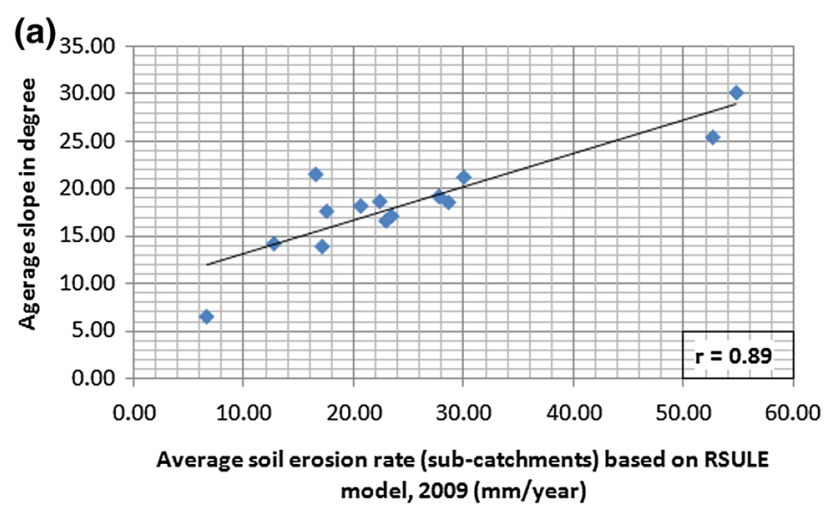

(b)

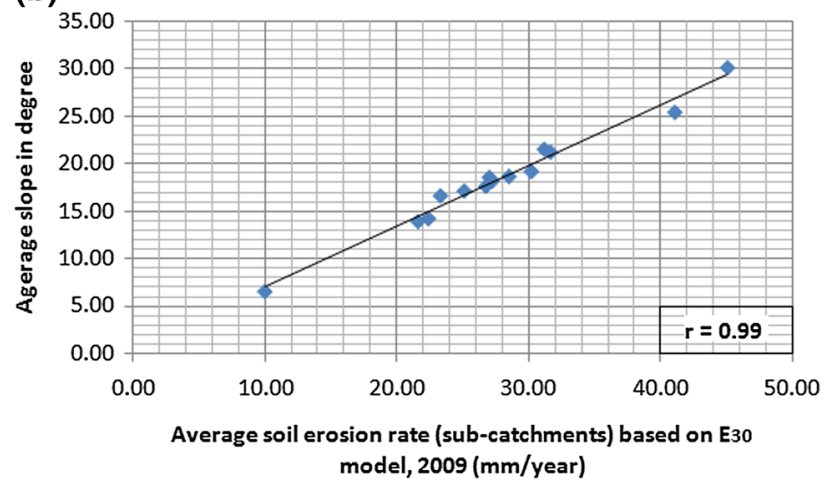

Fig. 7 Relationship between slope and estimated average erosion rate for sub-catchments through RUSLE (a) and $\mathrm{E}_{30}$ (b) model

there are no proper ground observation on the soil erosion measures.

\section{Compliance with ethical standards}

Conflict of interest The authors declare that there is no conflict of interest for the publication of this article.

\section{References}

Alexakis DD, Hadjimitsis Diofantos G, Athos A (2013) Integrated use of remote sensing, GIS and precipitation data for the assessment of soil erosion rate in the catchment area of Yialias in Cyprus. Atmos Res 131:108-124

Bagyaraj M, Ramkumar T, Venkatramanan S, Chung SY, Gurugnanam B (2014) Assessment of soil erosion probability in Kodaikanal, India using GIS and remote sensing. Disaster Advances 7(2):36-49

Darbral PP, Baithuri N, Pandey A (2008) Soil erosion assessment in a hilly catchment of North Eastern India using USLE, GIS and Remote Sensing. Water Resour Manag 22:1783-1798

Geobook (2009) Provincial GIS-based planning tools, Remote Sensing Centre, PO Box 320. University, NCD, Papua New Guinea

Gunawan G, Sutjiningsih D, Soeryantono H, Sulistioweni W (2013) Evaluation of erosion based on GIS and remote sensing for supporting integrated water resources conservation management. Int J Technol 4(2):147-156

Hazarika MK, Honda K (2001) Estimation of soil erosion using remote sensing and GIS, and its valuation and economic implication on agricultural production. In: 10th International soil Conservation Organization, Meeting at Purdue University and the USDA-ARS Soil Erosion Research Laboratory, pp 1090-1093

Honda K, Samarakoon L, Ishibashi A, Mabuchi Y, Miyajima S (1996) Remote sensing and GIS technologies for denudation estimation in Siwalik watershed of Nepal. In: Proceedings of the 17th Asian Conference on Remote sensing. Colombo, Sri Lanka, pp B21B26

Karaburun A (2010) Estimation of C factor for soil erosion modeling using NDVI in Buyukcekmece watershed. Ozean J Appl Sci 3(1):77-85

Kim HS, Julien PY (2006) Soil erosion modeling using RUSLE and GIS on the Imha watershed. Water Eng Res 7(1):29-41

Koloa C, Samanta S (2013) Development impact assessment along Merkham River through remote sensing and GIS technology. Int J Asian Acad Res Assoc 5(1):26-41

Kouli M, Soupios P, Vallianatos F (2009) Soil erosion prediction using the revised universal soil loss equation (RUSLE) in a GIS framework, Chania, Northwestern Crete, Greece. Environ Geol 57:483-497

Lillesand TM, Kiefer RW, Chipman JW (2007) Remote sensing and image interpretation, 6th edn. Wiley, New York, pp 1-772. ISBN:978-0-4700-5245-7

Lin WT, Lin CY, Chou WC (2006) Assessment of vegetation recovery and soil erosion at landslides caused by a catastrophic earthquake: a case study in Central Taiwan. Ecol Eng 28(1):79-89

Melesse AM, Ahmad S, McClain ME, Wang X, Lim YH (2011) Suspended sediment load prediction of river systems: an artificial neural network approach. Agric Water Manag 98:855-866

Michael EA, Samanta S (2016) Landslide vulnerability mapping (LVM) using weighted linear combination (WLC) model through remote sensing and GIS techniques. Model Earth Syst Environ 2:1-15. doi:10.1007/s40808-016-0141-7

Montgomery DR (2007) Soil erosion and agricultural sustainability. PNAS 104(33):13268-13272

Morgan RPC, Quinton JN, Smith RE, Govers G, Poesen JWA, Auerswald K, Chisci G, Torri D, Styczen ME (1998) The European soil erosion model (EUROSEM): a dynamic approach for predicting sediment transport from fields and small catchments. Earth Surf Proc Land 24(6):567-568

Pal B, Samanta S (2011) Estimation of soil loss using remote sensing and geographic information system techniques-case study, Kaliaghai River Basin, Purba \& Paschim Medinipur district, West Bengal, India. Indian J Sci Technol 4(10):1202-1207

Pal B, Samanta S, Pal DK (2012) Morphometric and hydrological analysis and mapping for watut watershed using remote sensing and GIS techniques. Int J Adv Eng Technol 2(1):357-368

Pandey A, Chowdary VM, Mal BC (2007) Identification of critical erosion prone areas in the small agricultural watershed using USLE, GIS and remote sensing. Water Resour Manag 21:729-746

Parveen R, Kumar U (2012) Integrated approach of universal soil loss equation (USLE) and geographical information system (GIS) for soil loss risk assessment in Upper South Koel Basin, Jharkhand. J Geogr Inf Syst 4:588-596

Pimentel D (2006) Soil erosion: a food and environmental threat. Environ Dev Sustain 8:119-137

Prasannakumar V, Shiny R, Geetha N (2011) Spatial prediction of soil erosion risk by remote sensing, GIS and RUSLE approach: a case study of Siruvani river watershed in Attapady valley, Kerala, India. Environ Earth Sci 64:965-972

Rahman MR, Shi ZH, Chongfa C (2009) Soil erosion hazard evaluation-an integrated use of remote sensing, GIS and 
statistical approaches with biophysical parameters towards management strategies. Ecol Model 220:1724-1734

Samanta S, Pal DK, Lohar D, Pal B (2012) Interpolation of climate variables and temperature modeling. Theor Appl Climatol 107(1):35-45. doi:10.1007/s00704-011-0455-3

Schertz DL (1983) The basic of soil loss tolerances. J Soil Water Conserv 38:10-14

Sharma A (2010) Integrating terrain and vegetation indices for identifying potential soil erosion risk area. Geo Spat Inf Sci 13(3):201-209

Sinha D, Joshi V (2012) Application of Universal Soil Loss Equation (USLE) to recently reclaimed Badlands along the Adula and Mahalungi Rivers, Pravara Basin, Maharashtra. J Geol Soc India 80:341-350

Symeonakis E, Drake N (2004) Monitoring desertification and land degradation over sub-Saharan Africa. Int $J$ Remote Sens 25(3):573-592

Tilley JR, Kell RAM, Haro A (2006) Protecting the Markham Bridge, Morobe Province, PNG. In: 9th International River Symposium. Brisbane
Tirkey AS, Pandey AC, Nathawat MS (2013) Use of satellite data, GIS and RUSLE for estimation of average annual soil loss in Daltonganj Watershed of Jharkhand (India). J Remote Sens Technol 1(1):20-30

Udayakumara EPN, Shrestha RP, Samarakoon L, Schmidt-Vogt D (2010) People's perception and socioeconomic determinants of soil erosion: a case study of Samanalawewa watershed, Sri Lanka. Int J Sedim Res 25:323-339

Van der Knijff, JM, Jones RJA, Montanarella L (2000) Soil erosion risk assessment in Europe, European Commission, European Soil Bureau,. http://eusoils.jrc.ec.europa.eu/ESDB_Archive/ pesera/pesera_cd/pdf/ereurnew2.pdf

Zhou W, Wu B (2008) Assessment of soil erosion and sediment delivery ratio using remote sensing and GIS: a case study of upstream Chaobaihe River catchment, north China. Int J Sedim Res 23:167-173

Zhou P, Luukkanen O, Tokola T, Nieminen J (2008) Effect of vegetation cover on soil erosion in a mountainous watershed. Catena 75:319-325 